\title{
Effects of organic insecticides, Kingbo and Azdar 10 EC, on mitotic chromosomes in root tip cells of Allium cepa
}

\author{
Mona S. Al-Ahmadi \\ Department of Biology, Science College for Girls, Dammam University, Dammam, Saudi Arabia.
}

Accepted 26 August, 2013

\begin{abstract}
In this study, two organic insecticides (Kingbo and Azdar 10EC) extracted from plants and used as agricultural pesticides were investigated for cytotoxic and genotoxic effects using root tips of Allium cepa assay. Three different concentrations $\left(0.625,1.62 \mathrm{~mL} . \mathrm{L}^{-1}\right.$ and $\left.2.5 \mathrm{~mL} . \mathrm{L}^{-1}\right)$ were used for different periods of time $(8,16$ and $24 \mathrm{~h})$. A single treatment of the effects of the two organic insecticides was used. The tested concentrations decreased the mitotic index compared to the control; $0.625 \mathrm{~mL}^{-1}$ of Kingbo treatment was statistically significant, while that of $1.62 \mathrm{~mL} . \mathrm{L}^{-1}$ for $16 \mathrm{~h}$ and $2.5 \mathrm{~mL} . \mathrm{L}^{-1}$ for 8 and $16 \mathrm{~h}$ increase the mitotic index. This increase was significant. Single treatment of Azdar 10EC decreased the mitotic index and its effect was non-significant compared to the control, while $2.5 \mathrm{~mL}^{-1}$ treatment for $\mathbf{2 4} \mathrm{h}$ increased the mitotic index and was statistically significant. In addition, the different treatments caused diverse types of chromosome abnormalites during metaphase, anaphase and telophase stages, and they were statistically significant after treating with 0.625 and $1.62 \mathrm{~mL}^{-1} \mathrm{~L}^{-1} \mathrm{King} \mathrm{bo}$ for 8 and $16 \mathrm{~h}$ and $0.625 \mathrm{~mL} . \mathrm{L}^{-1}$ Azdar $10 \mathrm{EC}$ for $8 \mathrm{~h}$. The chromosomes abnormalites were stickiness, disturbance, c-metaphase, c-anaphase, stare metaphase, chromosome bridges in anaphase and telophase, lagging chromosome and micronuclei appearing in interphase cells. The result indicates that both organic insecticides had cytotoxic and genotoxic activities on mitotic index and chromosomal aberration.
\end{abstract}

Key words: Organic insecticides, mitotic chromosomes, root tips, Allium cepa.

\section{INTRODUCTION}

The use of plant material or crude plant extracts for the protection of crops and stored products from insect pests is probably as old as crop protection itself (Thacker, 2002). Cytogenetic effects of synthetic chemical used for plant protection have been well documented and previously investigated by many authors (Qureshi et al., 1988; Vyuyan, 2002; Mekki, 2008). Almost all studies confirm the harmful effects of synthetic chemicals used in agriculture and increase in environmental pollution, which is a global problem (Soliman, 2010).

Some plants contain components that are toxic to pathogens. When extracted from the plant and applied on infested crops, these components are called botanical pesticides or botanicals (Malkhan et al., 2012). The secondary compounds of plants are a vast repository of compounds with wide range of biological activities. Unlike compounds synthesized in laboratories, secondary compounds from plants are virtually guaranteed to have biological activity and that activity functions highly in protecting the producing plant from a pathogen, herbivore or competitor (Duke, 1990).

Yet, many reports reveal that drugs of plant origin are 


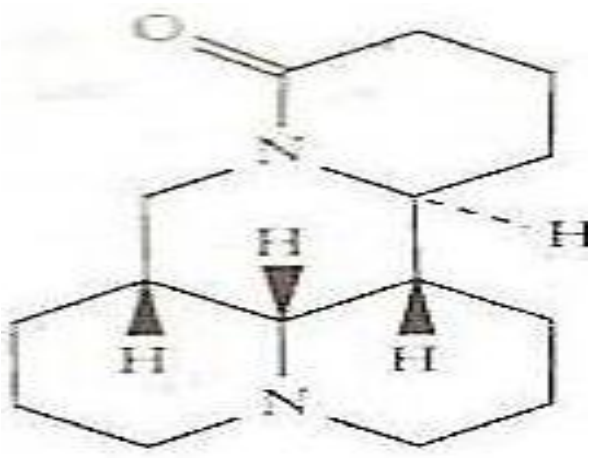

Figure 1. Chemical structure of matrine "merck index, eleventh Edition".

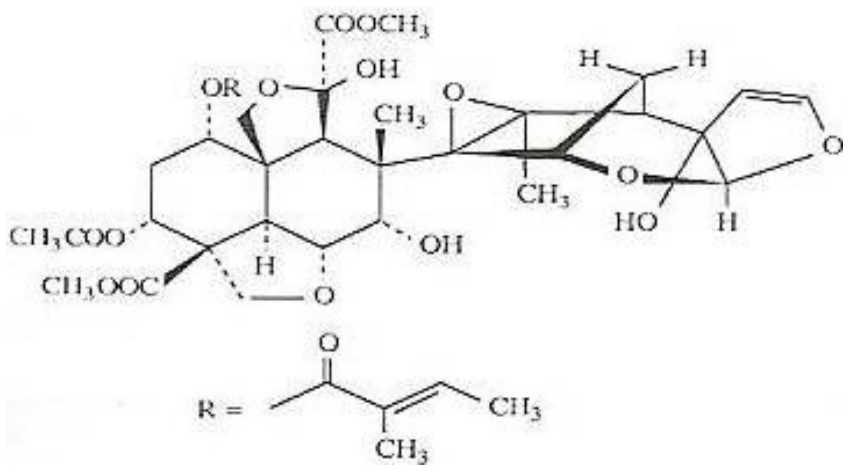

Figure 2. Chemical structure of Azadirachtin" merck index, eleventh Edition".

not free from toxic effects (Sousa et al., 2009). A number of plants extracts have been reported to have antimitotic and chromosome damaging properties. Yadav and Rathore (1984) investigate the aqueous fruit extracts of Emblica offkinalis; Sobita and Bhagirath (2005) investigate the effect of extracts of Nerium odorum, Andrographis peniculata, Nyctanthes arbortris-tis, phlogacanthus thyrsiflorus, Solanum indicum and Kaempferia galangal ; Mondal et al. (2006) investigated the effect of different Ipomosea species; Adegbite and Sanyaolu (2009) investigated the effect of Vernonia amygdalina Del. Leaf; Surendrajit and Bhagirath (2011) investigated the aqueous effect of Croton caudatus Geiseler leaves; Tülay (2012) investigates the effect of plant extracts; Al-Ahmadi (2013) investigated the effects of organic insecticides (Baicao No.2 and Baicao No.3) extracted from plants.

Regarding plant bioassay, Allium cepa, Lactus sativa, Zea mays and Vicia faba have been the most common species used for cytogenotoxicity evaluation. These species also show high sensibility to toxic compounds and they do not have small chromosomes (Singh and Das, 2002; Lubini et al., 2008; Sousa et al., 2009).

In this study, two botanical insecticides (Kingbo and Azdar 10 EC) were investigated for their cytotoxicity and genotoxcity to measure their harmful effects on chromosomes during the M-phases of cell cycle that may lead to death of cells. Root tips of $A$. cepa were used as an experimental material.

\section{MATERIALS AND METHODS}

\section{Tested materials}

Kingbo is a botanical insecticide, a product of Beijing Kingbo Biotech Company Limited., China. It is extracted from wild medical plant, Sophora flavescens Ait and natural oils. Its effective ingredient is $0.6 \%$ Matrine $\mathrm{C}_{15} \mathrm{H}_{24} \mathrm{~N}_{2} \mathrm{O}$, with mol. wt. of 248.36 (Figure 1). It can be used on a wide variety of plants such as vegetables, fruit trees, shrubs, grapes, grasses and flowers, and its recommended dosage is $2-2.5 \mathrm{~mL}^{-\mathrm{L}^{-1}}$. Azdar $10 \mathrm{EC}$ is also a botanical insecticide, a product of T.Stanes \& Company Limited., India; it is a tetranortriterpinoid isolated from the seeds of the neem tree, Azdirachta indica A. juss. Its effective ingredient is Azadirachtin A (10 g/L) $\mathrm{C}_{35} \mathrm{H}_{44} \mathrm{O}_{16}$, with mol. wt. of 720.73 (Figure 2). It is used for whitefly, thrips, cutworms, aphids, scale insects, bollworm, citrus and tomato leaf miner; its recommended dosage is $2-2.5 \mathrm{~mL} . \mathrm{L}^{-1}$.

\section{Sample preparations}

Plant test system is widely used for monitoring genotoxcity of chemicals due to many advantages, such as low cost, availability throughout the year, ease of handling, good chromosome condition for the study of chromosome damage and good correlation with other test systems (Sobita and Bhagirath, 2005). In this study, $A$. cepa $(2 \mathrm{~N}=16)$ root tips were used as an experimental material. Healthy onion bulbs were obtained from local markets. The loose outer scales and old roots of the onion were scraped and suspended in small beaker with distilled water.

\section{Treatments}

A. cepa was suspended in a small beaker $(50 \mathrm{ml})$ with distilled water to enhance the growth of the root tips until they reach $0.5-1$ $\mathrm{cm}$ in length; then it was transferred to another beaker containing freshely prepared solution of botanical insecticides and left for different periods of time. Three different concentraions for three different periods of time were used, and one bulb of onion was used for each treatment.

Negative control for each time was used; the root tips of $A$. cepa were treated with distilled water only, and used as a comparative sample for the effects of tested organic inscticides.

Three different concentrations $\left(0.625,1.62\right.$ and $\left.2.5 \mathrm{~mL} . \mathrm{L}^{-1}\right)$ were prepaerd to investigate the effect of the recommnded dosage, half and quarter of the recommended dosage for both insecticides. Single effect of the insecticides was examined.

\section{Slides preparation}

The roots were treated with different concentrations $(0.625,1.62$ and $\left.2.5 \mathrm{~mL} . \mathrm{L}^{-1}\right)$ for different periods of time $(8,16,24 \mathrm{~h})$, then the roots were detached, fixed in freshly prepared $3: 1(\mathrm{v} / \mathrm{v})$ ethanol alcohol and glacial acetic acid for $24 \mathrm{~h}$. Root tips of $A$. cepa were hydrolyzed in $1 \mathrm{~N} \mathrm{HCL}$ at 60 degrees centigrade for $8 \mathrm{~min}$; roots tips were then washed with distilled water several times and staind with $1 \%$ acetocarmin. Five temporary slides were prepared using the squash technique. Two root tips on each slide were examined for the effects of botanical insecticides on mitotic index (MI). The 
Table 1. Total number of examined cells, mitotic index and aberration frequency after treatment with different concentrations of organic insecticides for different periods of time on cells of root tip of Allium cepa.

\begin{tabular}{|c|c|c|c|c|c|c|c|}
\hline $\begin{array}{l}\text { Tested } \\
\text { material }\end{array}$ & $\begin{array}{c}\text { Concentration } \\
\text { (MI/L) }\end{array}$ & $\begin{array}{l}\text { Treatment/ } \\
\text { hour }\end{array}$ & $\begin{array}{l}\text { Number total } \\
\text { cells }\end{array}$ & $\begin{array}{l}\text { Divided } \\
\text { cell }\end{array}$ & $\begin{array}{l}\text { Total number of } \\
\text { abnormal cell }\end{array}$ & $\begin{array}{c}\text { mitotic } \\
\text { index }\end{array}$ & $\begin{array}{c}\text { Chromosomal } \\
\text { Aberration frequency }\end{array}$ \\
\hline \multirow{3}{*}{ Control } & d.water & 8 & 2062 & 218 & 13 & 10 & 0.06 \\
\hline & d.water & 16 & 2316 & 215 & 4 & 9.3 & 0.04 \\
\hline & d.water & 24 & 2217 & 302 & 5 & 13.6 & 0.02 \\
\hline \multirow{9}{*}{ Kingbo } & 0.625 & 8 & 2019 & 139 & 25 & $6.9^{*}$ & $0.18^{*}$ \\
\hline & 0.625 & 16 & 2156 & 157 & 13 & 7.3 & 0.08 \\
\hline & 0.625 & 24 & 2153 & 155 & 16 & 7.2 & 0.1 \\
\hline & 1.62 & 8 & 2430 & 208 & 28 & 8.6 & 0.13 \\
\hline & 1.62 & 16 & 2151 & 233 & 24 & $10.8^{*}$ & $0.1^{*}$ \\
\hline & 1.62 & 24 & 2234 & 171 & 30 & 7.7 & 0.18 \\
\hline & 2.5 & 8 & 2501 & 266 & 17 & $10.6^{*}$ & 0.06 \\
\hline & 2.5 & 16 & 2151 & 230 & 24 & $10.7^{*}$ & 0.1 \\
\hline & 2.5 & 24 & 2092 & 180 & 11 & 8.6 & 0.06 \\
\hline \multirow{9}{*}{ azdar $10 \mathrm{EC}$} & 0.625 & 8 & 2146 & 190 & 21 & 8.9 & $0.11^{*}$ \\
\hline & 0.625 & 16 & 2195 & 144 & 13 & 6.6 & 0.1 \\
\hline & 0.625 & 24 & 2114 & 114 & 21 & 5.4 & 0.2 \\
\hline & 1.62 & 8 & 2200 & 176 & 15 & 8 & 0.09 \\
\hline & 1.62 & 16 & 2310 & 153 & 15 & 6.6 & 0.1 \\
\hline & 1.62 & 24 & 2077 & 235 & 20 & 11.3 & 0.09 \\
\hline & 2.5 & 8 & 2498 & 149 & 13 & 6 & 0.09 \\
\hline & 2.5 & 16 & 2100 & 279 & 33 & 13.3 & 0.12 \\
\hline & 2.5 & 24 & 2203 & 326 & 26 & $14.8^{*}$ & 0.08 \\
\hline
\end{tabular}

*Significant at 0.05 .

same slides were analysed for the types and frequencies of chromosomal abnormalities (CF) produced by the examined insecticides.

\section{Scoring of slides and data analysis}

The slides were viewed under light microscope (Phenix $\mathrm{P} \mathrm{H} 50$ DB047VU) using the 40X objective lens immersion. The most representative ones for each structural aberration were photographed using Phenix micro Image analyzer Software 2008 En V2, 2.

\section{Mitotic index}

On one slide for each treatment, a total of 2000 cells were scored. The mitotic index (MI) was expressed as the number of dividing cells per total cells scored, as seen in the following equation:

Mitotic Index (MI) $=\frac{\text { Total number of dividing cell }}{\text { Total number of cell examined }} \times 100$

\section{Cytotoxicity}

The mitotic index of the treated cells at each dose of each insecticide was compared with that of the negative control group

\section{Genotoxicity test}

Chromosomal aberrations per dose of each insecticide were examined. The cells with aberrations of each dose for each insecticide were compared with that of the negative control using the SPSS 16.0 for Windows statistical package. Two-way Analysis of Variance was the statistical method used for determining the significance of difference at $\mathrm{P}=0.05$.

chromosomal aberration frequency $(\mathrm{CF})=\frac{\text { Total number of abnormal cell }}{\text { Total number of divided cell }}$

\section{RESULT AND DISCUSSION}

\section{Mitotic index (MI)}

Table 1 and Figures 3 and 4 show the data of total cells counted in microscopic observations. Mitotic index (MI) which measures the proportion of cells in the M-phase of cell cycle inhibition could be considered as cellular death or delay in the cell proliferation kinetics (Rojas et al., 1993; chromosomal aberration frequency (CF) that reveals chromosomes aberrations was observed after treatment with tested material.

The mitotic index of root tip cells that were treated with different concentrations of Kingbo and Azdar 10EC $\left(0.625,1.62\right.$ and $\left.2.5 \mathrm{~mL} . \mathrm{L}^{-1}\right)$ for different periods of time $(8,16$ and $24 \mathrm{~h})$ decreased compared to that of the negative control (root tips treated with distilled water only). Root tips treated with Kingbo show increase in (MI) after 


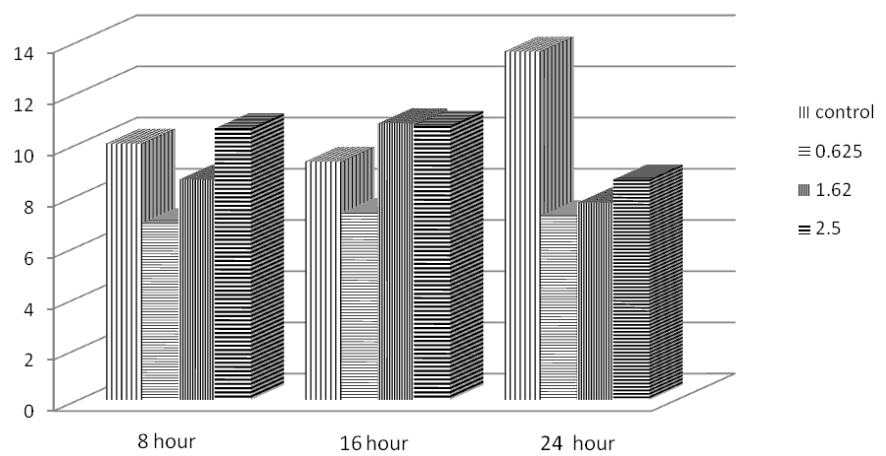

Figure 3. Effect of different concentrations of Kingbo on mitotic index on root tip cells of $A$. cepa.

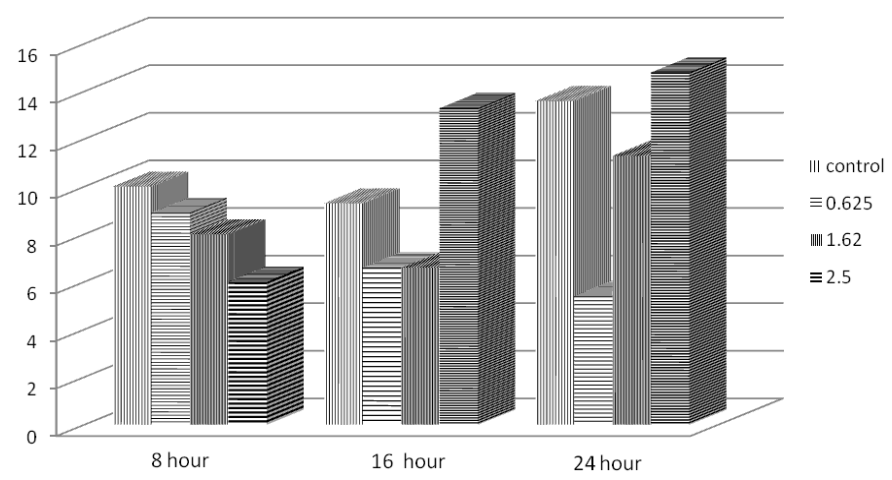

Figure 4. Effect of different concentrations of Azdar $10 \mathrm{EC}$ on mitotic index on root tip cells of $A$. cepa.

treating with $1.62 \mathrm{~mL} . \mathrm{L}^{-1}$ for $16 \mathrm{~h}$, and with the highest concentration $\left(2.5 \mathrm{~mL} . \mathrm{L}^{-1}\right)$ for 8 and $16 \mathrm{~h}$. Also the decrease of mitotic index was statistically significant after treating with $0.625 \mathrm{~mL} / \mathrm{L}^{-1}$ of Kingbo for $8 \mathrm{~h}$.

Treatment with different concentrations of Azdar 10EC decreased the $(\mathrm{MI})$ with increase in tested concentration and time of exposure, except for treatment with the highest concentration $\left(2.5 \mathrm{~mL} . \mathrm{L}^{-1}\right)$ for $24 \mathrm{~h}$ which increased the mitotic index compared to the negative control.

Reduction in mitotic index could be due to the inhibition of DNA synthesis or blocking the cell from entering mitosis (Sudhakar et al., 2001; Tülay and Ozlem, 2010), Yadav (1986) reported that mitotic index can be disrupted in three ways: (1) by inhibiting the process of cell division, (2) by disturbing the normal functioning of mitotic spindle and (3) by producing chromosomal abnormalities which lead to mitotic index reduction. Also, Vyuyan (2002) explains that the decrease of the mitotic index because of the increased number of interphase or dead cells and accumulation of interphase cells may be due to the inhibition of DNA synthesis and this inhibition result, according to Njagi and Gopalan (1980), shows that plant extracts might interact with DNA subsequent mitotic inhabitation. Similar result was observed with Haff (1968),
Bruneri (1971), Sobita and Bhagirath (2005), Mondal et al. (2006) and Sazada et al. (2010).

These effects on mitotic index indicate a potential mitodepressive that leads to cytotoxic effects. Similar inhibition of cytokinesis cells was also reported by Borah and Talukdar (2002).

The increase of mitotic index may result from shortening the duration of mitotic cycle and allowing the interphase cells enter the subsequent division stages. Haroun and Al Shehri (2001), Haroun (2010) and Abderrahman (1997) found out that treatment with Peqonum harmala extraction increased the mitotic index of root tip cells of $A$. cepa.

\section{Chromosomal aberration (CA)}

Allium cepa assay is a sensitive test, and it has been shown to have correlation with tests in other living systems and serves as an indicator of toxicity of the tested material (Fiskesjo, 1985). Chromosomal aberrations (CA) are changes in chromosome structure that results from a break or exchange of chromosomal material (Swierenga et al., 1991).

Sobita and Bhagirath (2005) reported that chromosomal aberrations that resulted from different treatments indicate a clastogenic effect of the tested materials. Table 2 and Figures 5 and 6 show the result of single effect of the two organic insecticides on chromosomes of root tip cells of $A$. cepa.

Even though the control treatment had no tested concentrations of the insecticides, the apical meristem showed cytological abnormalities with low frequency. This might be due to the auto- mutagenic substance (Dubinin and Scerbako, 1962; Kaushik, 1996). Teas et al. (1965) suggested that as seedling roots increase in length, aberrations are less likely to continue in mitosis and when root becomes 2 to $3 \mathrm{~cm}$ in length, the aberration caused in control condition becomes insignificant, which means increase in mitotic index of control.

Cytological observation (Figure 7) indicates that all the tested concentrations of the two organic insecticides (0.625, 1.62 and $\left.2.5 \mathrm{~mL} . \mathrm{L}^{-1}\right)$ cause chromosome abnormalities mostly during metaphase, anaphase and telophase stages. They were statistically significant after treating with 0.625 and $1.62 \mathrm{~mL} . \mathrm{L}^{-1}$ Kingbo for 8 and $16 \mathrm{~h}$ and $0.625 \mathrm{~mL} . \mathrm{L}^{-}$Azdar $10 \mathrm{EC}^{1}$ for $8 \mathrm{~h}$. Most types of chromosome aberrations observed in high percentage were stickiness, disturbance, c-metaphase, chromosome bridges in anaphase and telophase, lagging chromosome and micronuclei appearing in interphase cells; while smetaphase, s-anaphase and fragments were observed in low percentage.

Treatment with Kingbo ( 0.625 and $\left.1.62 \mathrm{~mL} . \mathrm{L}^{-1}\right)$ caused high chromosome frequency after 8 and $16 \mathrm{~h}$ of exposure; also treatment with Azdar 10 EC (0.625 and 2.5 $\mathrm{mL} . \mathrm{L}^{-1}$ ) for 8 and for $16 \mathrm{~h}$ caused high chromosome aberration frequency compared to the control.

Chromosome stickiness means loss of normal appea- 
Table 2. Type of chromosomal aberrations on root tip cells of $A$. cepa after treatment with different concentrations of the tested organic insecticides for different periods of time.

\begin{tabular}{|c|c|c|c|c|c|c|c|c|c|c|c|c|c|c|c|c|c|c|c|}
\hline \multirow{2}{*}{$\begin{array}{l}\frac{0}{0} \\
: \frac{0}{0} \\
0 \\
0\end{array}$} & \multirow{2}{*}{ 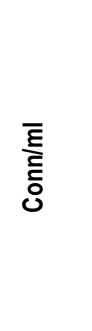 } & \multirow{2}{*}{ 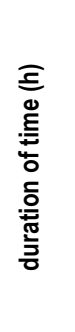 } & \multicolumn{5}{|c|}{ 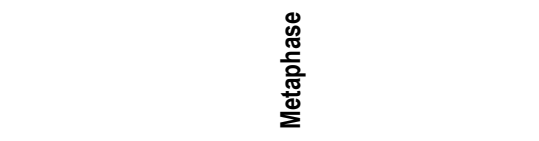 } & \multicolumn{5}{|c|}{ 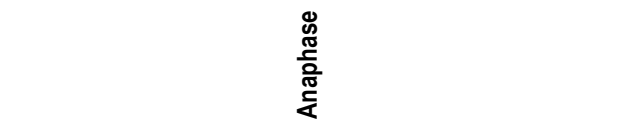 } & \multicolumn{4}{|c|}{ 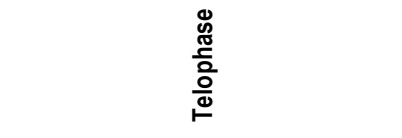 } & \multirow[b]{2}{*}{$\begin{array}{l}\overline{\bar{U}} \\
\bar{E} \\
\dot{\mathscr{E}}\end{array}$} & \multirow[b]{2}{*}{ 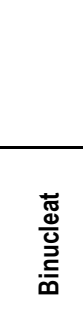 } & \multirow[b]{2}{*}{ ะั } \\
\hline & & & $\frac{\overrightarrow{0}}{\frac{0}{\omega}}$ & 起 & 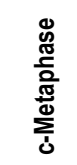 & 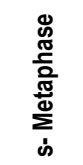 & 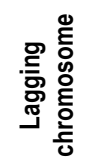 & 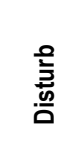 & 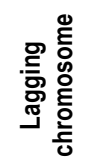 & $\frac{\mathscr{D}}{\frac{0}{0}}$ & 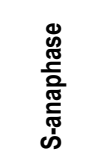 & 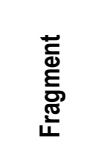 & 竞 & 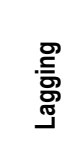 & 음 & 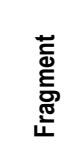 & & & \\
\hline \multirow{3}{*}{ Control } & \multirow{4}{*}{$\begin{array}{l}\text { Distell } \\
\text { water }\end{array}$} & 8 & 0.01 & 0.01 & & & & 0.01 & & 0.01 & & & & & & & & & 6 \\
\hline & & 16 & 0.3 & & 0.004 & & & 0.004 & & & & & & & & & & & 4 \\
\hline & & 24 & & 0.01 & & & & 0.003 & & & & & & 0.003 & & & & & 2 \\
\hline \multirow{9}{*}{ Kingbo } & & 8 & 0.04 & 0.04 & 0.03 & & & 0.02 & & & & 0.007 & & & & 0.007 & 0.04 & & 18 \\
\hline & \multirow[t]{2}{*}{0.625} & 16 & 0.04 & 0.01 & & & & 0.01 & & 0.01 & & & & 0.006 & & & & & 8 \\
\hline & & 24 & 0.03 & 0.03 & & & & & & 0.03 & & & & 0.02 & & & & & 10 \\
\hline & \multirow{3}{*}{1.62} & 8 & 0.04 & 0.03 & 0.02 & & 0.005 & 0.01 & & 0.02 & & & & & & & & & 1 \\
\hline & & 16 & 0.03 & 0.03 & & & & 0.004 & & 0.04 & & & & & & & & & 10 \\
\hline & & 24 & 0.09 & 0.04 & & & & 0.02 & 0.006 & 0.02 & & & & 0.006 & 0.006 & & & & 18 \\
\hline & \multirow{3}{*}{2.5} & 8 & 0.004 & 0.004 & & & & 0.004 & & 0.05 & & & & & & & 0.008 & & 7 \\
\hline & & 16 & 0.02 & 0.03 & & & & 0.02 & & 0.03 & & & 0.007 & & & & & & 10 \\
\hline & & 24 & 0.006 & 0.04 & & & & 0.006 & & 0.01 & & & & & & & & & 6 \\
\hline \multirow{9}{*}{$\begin{array}{c}\text { Azdar } 10 \\
\text { EC }\end{array}$} & \multirow{3}{*}{0.625} & 8 & 0.01 & 0.06 & & & & 0.005 & & 0.03 & & & & & & & 0.005 & & 11 \\
\hline & & 16 & 0.02 & 0.03 & 0.02 & & & & & 0.01 & & & & & & & & & 10 \\
\hline & & 24 & 0.05 & 0.05 & & & & 0.03 & 0.04 & & & & & & & & & & 20 \\
\hline & \multirow{3}{*}{1.62} & 8 & 0.02 & 0.02 & & & & 0.02 & & 0.02 & & & & 0.006 & 0.006 & & & & 9 \\
\hline & & 16 & 0.01 & 0.04 & & & & & 0.007 & 0.01 & 0.007 & & & & 0.007 & & 0.01 & & 9 \\
\hline & & 24 & 0.02 & 0.03 & & & 0.004 & 0.004 & & 0.03 & & & & & & & & & 9 \\
\hline & \multirow{3}{*}{2.5} & 8 & 0.03 & & 0.02 & & 0.007 & 0.02 & & 0.007 & & & & & & & 0.007 & & 9 \\
\hline & & 16 & 0.02 & 0.02 & & 0.004 & & 0.01 & & 0.05 & & & & 0.007 & & & 0.004 & 0.007 & 12 \\
\hline & & 24 & 0.009 & 0.04 & & & & 0.003 & 0.003 & 0.02 & & & & 0.003 & & & 0.003 & & 8 \\
\hline
\end{tabular}

rance, and it is seen with sticky surface, causing chromosomes agglomeration (Babich et al., 1997). It might be due to the effect of pollutants and chemical compounds on the physical-chemical properties of DNA, protein or both, the formation of complexes with phosphate group in DNA, DNA condensation or formation of inter and intra chromatid cross links (Shahin and $\mathrm{El}$ Amoodi, 1991; Turkogul, 2007; Tülay and Ozlem, 2010). Also stickiness might be due to the deploymerization and partial dissolution of nucleoproteins, breakage and exchange of the basic folded units of chromatids and the stripling of the protein covering of DNA in chromosomes Onyenwe
(1983). Disturbance during metaphase and anaphase, star metaphase, star anaphase arises because of the effect of the treatment on the spindle that leads to failure of spindle mechanism (Yadav, 1986).Khakdan and Piri (2012) suggested that plant extracts act as a toxic agent on formation of the mitotic spindle, with the chemical action 


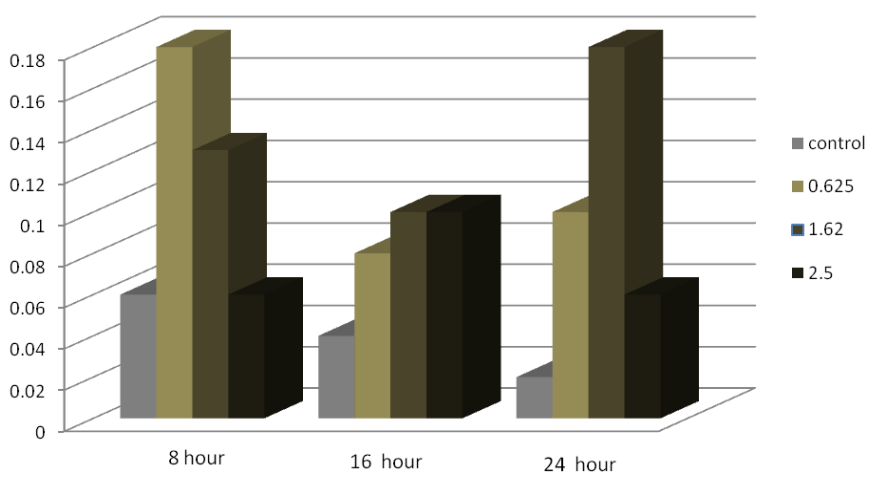

Figure 5. Effect of different concentrations of Kingbo on chromosomal aberretions on root tip cells of $A$. cepa.

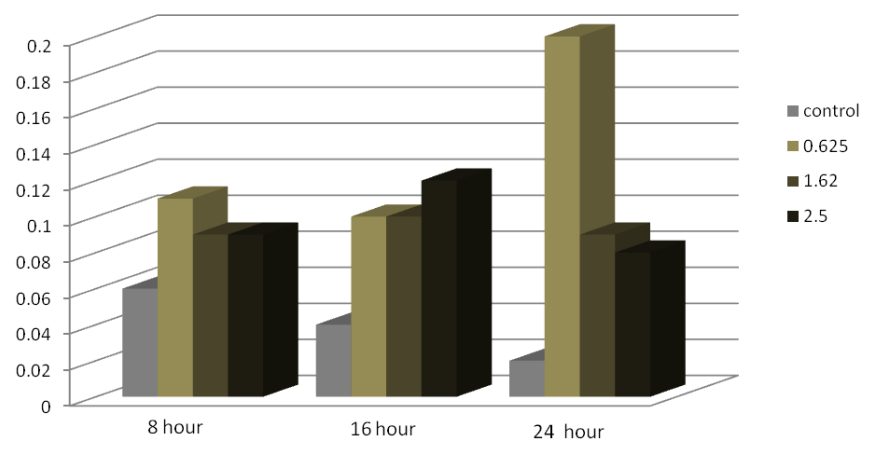

Figure 6. Effect of different concentrations of Azdar 10 EC on chromosomal aberrations on root tip cells of $A$. cepa.
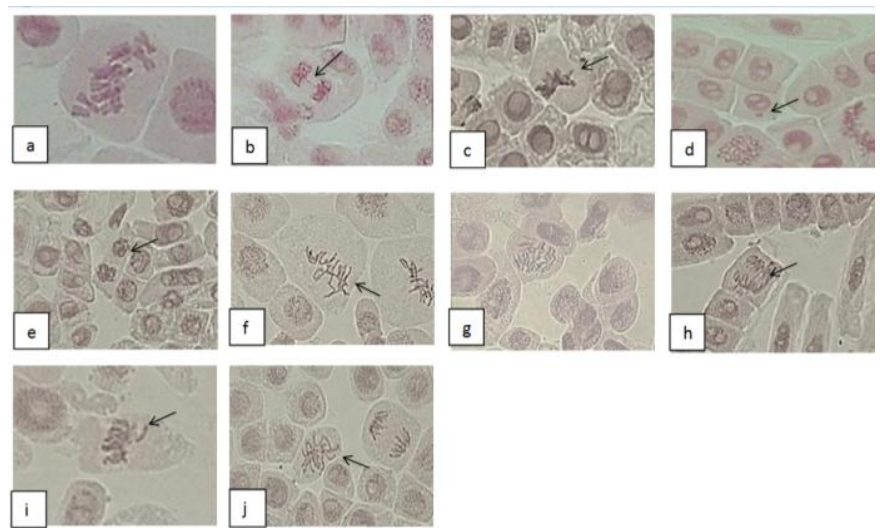

Figure 7. Type of chromosomal aberrations after treatment with different concentration of two organic insecticides on root tip cells of $A$. cepa (a-e: type of chromosomal aberration after treatment with kingbo, $f-j$ : type of chromosomal aberration after treatment with Azdar-10EC) : a- C- metaphase. b- bridge on telophase. csticky metaphase. $d$ - micronuclei. e- sticky telophase. $f$ - disturb metaphase. $\mathrm{g}$ - disturb anaphase. $\mathrm{h}$ - bridge on anaphase. $\mathrm{i}$ - lagging chromosome on metaphase. $\mathrm{j}$ - disturb metaphase.

on DNA or the DNA- protein complex. Also Ndubuisi and Bosa (2010) reported that, the root extracts of
Boerhaavia diffusa had a nucleotoxic action.

Chromosomes bridge during anaphase and telophase raises when the chromosomes fail to separate because of chromosomes stickiness Yadav (1986). Chromosome fragment is an indication of chromosome break, and can be a consequence of anaphase/telophase bridges (Singh, 2003). Also, Darlington (1942) reported that stickiness may result in fragmentation of chromosomes from the stress of anaphase movement or in the bridge formation when the chromosomes fail to separate.

C-metaphase (colchicine metaphase) appeared because of the inactivation of the spindle followed by a random scattering of the chromosomes over the cell (Levan, 1938; Auti et al., 2010). Micronuclei (MN) often result from the acentric fragments or lagging chromosomes that fail to incorporate into daughter nuclei during telophase of the mitotic cells and can cause cellular death due to the deletion of primary genes (Albertini et al., 2000; Krishna and Hayashi, 2000; Tülay and Ozlem, 2010).

\section{Conclusion}

The result of this study indicates that the single treatment of these two organic insecticides (Kingbo and Azdar 10 EC) decreased the mitotic index and was statistically significant. Still, some examined concentrations of the investigated insecticides caused an increase in the mitotic index. Furthermore, different treatments of the organic insecticides caused chromosomes abnormalities such as stickiness, disturbance, chromosome bridges on anaphase and telophase stage, lagging and fragments. Decrease in the mitotic index and increase in the chromosomal aberration frequency indicates that they had a cytotoxic effect on cells division; chromosomes abnormalities indicate that the two insectcides have a clastogenic property that leads to genotoxic effects. In addition, Kingbo was more effec-tive in mitotic index and chromosomes abnormalities than Azdar 10EC.

\section{REFERENCES}

Abderrahman SM (1997). Effects of Peganum harmala extract on root tips of Allium cepa. Cytologia. 90: 171-174.

Adegbite AE, Sanyaolu EB (2009). Cytotoxicity testing of aqueous extract of bitter leaf Vernonia amygdalina Del. using the Allium cepa chromosome aberration assay. Sci. Res. Essay. 4 (11): 1311-1314.

Al-Ahmadi MS (2013). Cytogenetic effects of tow organic insecticides on mitotic chromosomes of Allium sativum root tip cells. J. Pharm. Biol. Sci. 4 (6): 17-22.

Albertini RJ, Anderson D, Douglas GR (2000). IPCS guidelines for the monitoring of genotoxic effects of carcinogen in humans. Mutation Res. 463(2):111-172.

Auti S, Pagare R, Ahire D, Sawale V (2010). Cytogenetical studies on the effect of omnacortil on root tip cells of Allium cepa. J. Cell Tissue Res. 10 (3):2331- 2335.

Babich H, Segall MA, Fox KD (1997).The Allium cepa test- a simple, eukaryote genotoxicity assay. American Biology Teacher. 59 (9):580-583. 
Bruneri (1971). Synthesis of DNA and mitosis in relation to cell differentiation in the root of Vicia faba and Lactuca sativa. Cytologia. 36: 229-247.

Borah SP, Talukdar J (2002). Studies on the cytotoxic effects of extract of castor seed Ricinus communis. Cytologia. 67 (3): 235243.

Darlington CD (1942). Chromosome chemistry and gene action. Nat. 149: 66-69.

Dubinin NP, Scerbako (1962). Control of the natural mutation process by means of cysteamine and streptomycin. Proc. Acad. Sci. USSR. 145: 427-429.

Duke SO (1990). Natural pesticides from plants. In: J. Janick and J. E. Simon ( eds.), Advances in new corps. Timber Press, Portland. OR: 511-517.

Fiskesjo G (1985). The Allium test as a standard in environmental monitoring. Hereditas. 102: 99- 112.

Haff VJ (1968). The action of IAA and kinetin on the mitotic cucle of proliferative and stationary phase excised root meristem. Exp. Cell Res. 51:167.

Haroun SA (2010). Mutageneic effects of Kochia indica extract on Vicia faba L. J. Amer. Sci. 6 (7): 292-297.

Haroun SA, Al- shehri AM (2001). Cytogenetic effects of Calotropis procera extract on Vicia faba . Cytologia. 66: 373- 378.

Kaushik SC (1996). Cytological effects of Lantana camara L. leaves extract on Vicia faba root tip cells. Advanced plant Science. 9:159164.

Khakdan F, Piri K (2012). Cytotoxic and genotoxic effects of aqueous root extract of Arctiun lappa on Allium cepa Linn root tip cells. International journal of Agronomy and Plant Production. 3 (12): 630 637.

Krishna G, Hayashi M (2000). In vivo rodent micronucleus assay: protocol, conduct and data interpretation. Mutation research.455(12): $155-166$

Levan A (1938). Effect of colchicine on root mitosis in Allium cepa. Herediatas.24: $471-486$

Lubini G, Fachinetto JM, Laughinghouse HD, Paranhos JT, Silva ACF, Tedesco SB (2008). Extracts affecting mitotic division in root -tip meristematic cells. Biologia. 63: 647- 651.

Malkhan SG, Shahid MA, Kangabam SS (2012). Efficacy of plant extracts in plant disease management. Agric. Sci. 3(3): 425-433.

Mekki LE (2008). The effect of three agricultural chemicals on mitotic division and seed protein banding profiles of Vicia faba. I. J. Agric. Biol. 10 (5):499-504.

Mondal A, Kabri G, Yasmin N, Alam, AMS, Khatun HA (2006). Mitotic effect of water extract of different Ipomosea Species on Allium cepa L. Pakistan J. Biol. Sci. 9: 1116-1120.

Ndubuisi MC, Bosa EO (2010). Cytological effects of the root extracts of Boerhaavia diffusa on root tips of Crinum jagus. Eur Asian J. BioSciences. 4: 105-111.

Njagi GDE, Gopalan HNB (1980). DNA and its precursors might inter with the food preservatives, sodium sulphite and benzoate. Experimentia. 36: 413-414.

Onyenwe CN (1983). Cytological effects of seed extracts of Abrs procatorius on the mitosis of Allium cepa and the effect of root extracts of Boerhaavia diffusa on mitosis of Crassocephallum biafrae. University of Port Harcourt.

Qureshi S, Tariq M, Parmar NS, Al-Mashal IA (1988). Cytological effect of Khat ( Cathaedulis) in somatic and male germ cells of mice. Drug Chem. Toxicol. 11:151-165.

Rojas E, Herrera A, Sordo M (1993). Mitotic index and cell proliferation kinetics for identification of antineoplastic activity. AntiCancer Drugs. 4(6): 637- 640

Sazada S, Saad A, Meghvansi MK, Shouket SK, Ayaz AR, Arti V (2010). Evaluating the toxic effects of Ficus infectoria Roxb. And Emblica officinalis Gaertn. Leaf extracts on cell division and chromosomal morphology of Cicer arietinum L. J. Ecobiotechnol. 2 (1): 49-52.

Shahin SA, El-Amoodi HH (1991). Induction of numerical chromosomal aberrations during DNA synthesis using the fungicides nimrod and rubigan-4 in root tips of vicia faba $L$. Mutation Res. 261(3): 169-176.
Singh RJ (2003). Plant cytogenetics. CRC Press, Boca Raton. Pp.463.

Singh RB, Das UC (2002). Chromotoxic and mito- inhibitory effects of Lathyrus sativus seed extract on root tip cells of Vicia faba. J. Ecotoxicol. Environ. Monitoring. 12: 95- 99.

Sobita K, Bhagirath TH (2005). Effects of some medicinal plant extracts on Vicia faba root tip chromosomes. Cytologia. 58 (3):255261

Soliman AH (2010). Mutageneic effects of Kochia indica extract on Vicia faba L. J. Amer. Sci. 6 (7):292-297.

Sousa SM, Pamela SS, Jose MS, Campos LFV (2009). Cytogenetic and genotoxic effects of two medicinal species of Verbanaceae. Caryologia. 62 (4):326- 333.

Sudhakar R, Ninge GKN, Venu G (2001). Mitotic abnormalities induced by silk dyeing industry effluents in the cells of Allium cepa. Cytologia. 66 (3):235-239

Surendrajit L, Bhagirath T (2011). Evaluation of genotoxic effects of aqueous of Croton caudatus Geiseler leaves on mice. Caryolgia. 64 (4):365-369.

Swierenga SHH, Heddle JA, Sigal EA, Gilman JPW, Brillinger RL, Douglas GR, Nestmann ER (1991). Recommended protocols based on a survey of current practice in genotoxicity testing laboratories, IV. Chromosome aberrations and sister-chromatid exchange un Chinese hamster ovary, V79 Chinese hamster lung and human lymphocyte cultures. Mutation Res. 246: 301-322.

Teas HJ, Sax HJ, San K (1965). Cycasin: Radiomimetic. Science. 149:541-542.

Thacker JRM (2002). An Introduction to Arthropod pest control. Cambridge University Press, Cambridge, U.K.

Tülay AC and Ozlem SA (2010). Evaluation of cytotoxicity of Inula viscosa extracts with Allium cepa Test. J. Biomed. Biotechnol. 2010:1-7.

Tülay AC (2012). Potential Genotoxic and Cytotoxic Effects of Plant Extracts, A Compendium of Essays on Alternative Therapy, Dr. Arup Bhattacharya (Ed.), ISBN: 978-953-307-863-2.

Turkogul S (2007). Genotoxicity of five food preservatives tested on root tips of Allium cepa.Mutation research / Genetic Toxicology and Environmental Mutagenesis. 626 (1-2):4 - 14.

Vyuyan JR (2002). Allelochemicals as leads for new herbicides and agrochemicals. Tetrahedron.58:1639-1646.

Yadav SK, Rathore JS (1984). Cytological effects of the aqueous fruit extracts of Embilca officinalis on Allium sativum root tips. Egypt. J. Genet. Cylo. 13: 181-185.

Yadav SK (1986). Antimitotic and Cytological Activities of Tropical Forest Tree: Tamarindus indica. J. Trop. Forestry. 2(1): 53-58. 